2. To: (Receiving organization)

FFTF Planning/Scheduling Integration

FFTF

8. Originator Remarks:

These calculations were done to support the FFTF fuel offload.

11. Receiver Remarks: 11A. Design Baseline Document? [] Yes [X] No
5. Proj./Prog./Dept./Div.:
3. From: (originating organization)

Criticality and Shielding

6. Design Authority/ Design Agent/Cog Engr : :

S. F. Kessler
4. Related EDT No.:

620286

7. Purchase Order No.:

NA

9. Equip./Component $\mathrm{No}$ :

NA

10. Systen/Bldg./Facility:

FFTF

12. Major Assm. Dwg. No.:

NA

13. Permit/Permit Application No.: NA

14. Required Response Date: $1 / 24 / 97$

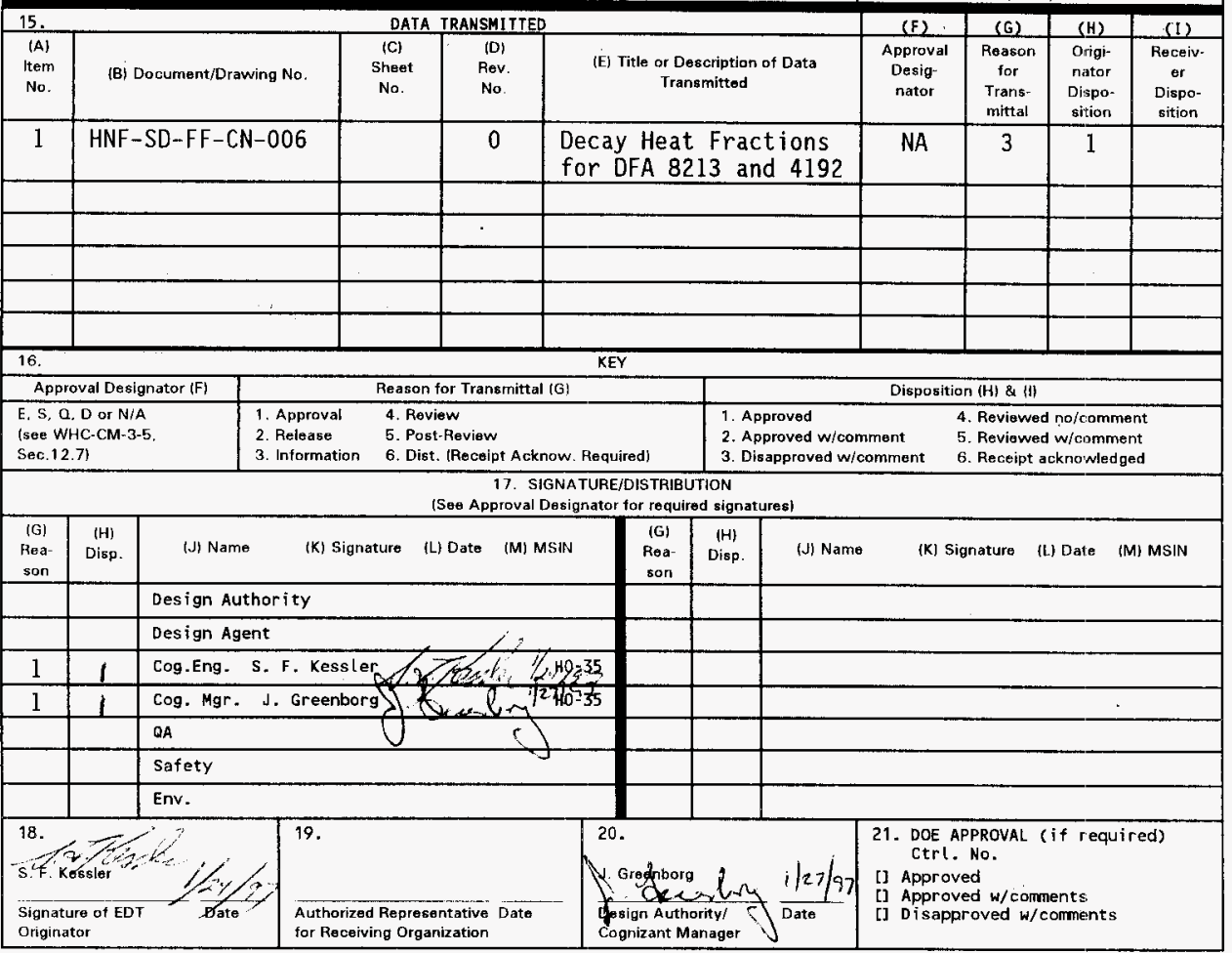




\section{Decay Heat Fractions for DFA 8213 and 4192}

S. F. Kessler

Fluor Daniel Northwest, Richland, WA 99352

U.S. Department of Energy Contract DE-AC06-96RL13200

$\begin{array}{lll}\text { EDT/ECN: } & 620286 & \text { UC: } 510 \\ \text { Org Code: } & 403 & \text { Charge Code: } \\ \text { B\&R Code: } & \text { EX7003000 } & \text { Total Pages: } 4\end{array}$

Key Words: Decay Heat Driver Fuel, FFTF, Interim Storage Cask

Abstract: Decay heat fractions for FFTF driver fuel assemblies 8213 and 4192 were calculated to allow the assembly nozzles to be cut. Cutting the nozzles is required to allow the assemblies to fit in the center location of a core component container in an Interim Storage Cask.

TRADEMARK DISCLALMER. Reference herein to any specific commercial product, process, or service by trade name, trademark, manufacturer, or otherwise, does not necessarily constitute or imply itis endorsement, recommendation, or favoring by the United states Government or any agency thereof or its contractors or subcontractors.

Printed in the United States of America. To obtain copies of this document, contact: WHC/BCs Document Control Services, P.O. Box 1970, Mailstop H6-08, Richland WA 99352, Phone (509) 372-2i420; Fax (509) 376-4989.
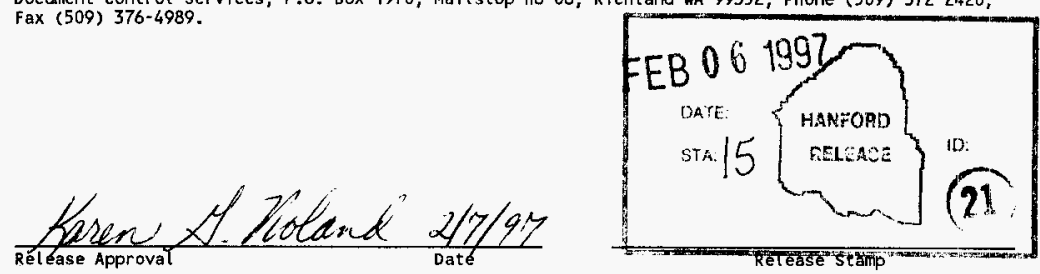

Approved for Public Release 


$$
\text { HNF-SD-FF-CN-006 REV } 0
$$

\section{DECAY HEAT FRACTIONS FOR DFA 8213 and 4192}

\subsection{PURPOSE}

When Fast Flux Test Facility (FFTF) driver fuel assemblies (DFA) are disassembled, the decay heat of each component must be calculated to ensure that decay heat limits for the storage vessels and handling machines will not be exceeded. Additionally, as DFA's are put in core component containers (CCC) inside interim storage casks (ISC), the assembly in the center location will have approximately one-half of its nozzle removed so it will fit. The purpose of this calc note is to provide the decay heat fractions for DFA 8213 and 4192 which wi11 be placed in the center positions of CCCs in ISCs.

\subsection{METHODOLOGY}

Calculation of the decay heat fractions is performed by the codes DKH1-4FRAC and SDKHEAT ${ }^{2}$. The references contain the specific procedures used to generate the decay heat fractions.

\subsection{ASSUMPTIONS}

The only assumptions made for this calculation is that half of the decay heat is removed with the cut portion of the nozzle and the remainder is added to the decay heat of the duct.

\subsection{INPUT DATA}

The input data for the DKH1-4FRAC code are the assembly type, serial number, and core location. SDKHEAT requires only the assembly serial number. DFA 8213 is an outer driver fuel assembly and was last irradiated in cycle $8 \mathrm{C}$ in core location 3506. DFA 4192 is also an outer driver fuel assembly and was last irradiated in cycle $10 \mathrm{C} 3$ in core location 1607.

\subsection{CALCULATION}

The 4-factor output of the DKHl-4FRAC code is listed for the assembly in table 5.1. From the calculations, the nozzle fraction is reduced by one-half to account for the portion of the nozzle that is removed. This same value is added to the duct fraction to account for the portion of the nozzle that remains attached to the duct, as shown in Section 6.0. 
TABLE 5.1: DECAY HEAT FRACTIONS FROM DKH1-4FRAC

\begin{tabular}{|c|c|c|}
\hline Assembly & 8213 & 4192 \\
\hline NOZ $========$ & 0.36434 & 0.32733 \\
\hline $\mathrm{PIN}===== \pm= \pm \overline{1}$ & 0.30469 & 0.32248 \\
\hline DUCT $========$ & 0.33009 & 0.34935 \\
\hline $\mathrm{HS}==========$ & 0.00088 & 0.00084 \\
\hline
\end{tabular}

\subsection{RESULTS}

The results are shown in table 6.1 for each assembly. This information cannot be obtained from the SDKHEAT diskettes; therefore, it should be placed in the decay heat notebook for use in handling and disposal of these components.

TABLE 6.1: CORRECTED DECAY HEAT FRACTIONS

Assembly 8213

$\begin{array}{lll}\mathrm{NOZ}========\Rightarrow> & 0.182 & 0.164 \\ \mathrm{PIN}========\Rightarrow> & 0.305 & 0.322 \\ \mathrm{DUCT}=======\Rightarrow & 0.512 & 0.513 \\ \mathrm{HS}==========> & 0.001 & 0.001\end{array}$

\subsection{REFERENCES}

1. R. A. Schwarz, "Certification of the DKH1-4FRAC Program", WHC-SD-FF-SWD046, Rev. 0, Westinghouse Hanford Company, Richland, Washington, October $30,1990$.

2. R. A. Schwarz, "SDKHEAT Symphony Decay Heat Program", WHC-SD-FF-SWD-033, Rev. 0-C, Westinghouse Hanford Company, Richland, Washington, October 17, 1995. 


\section{CHECKLIST FOR INDEPENDENT TECHNICAL REVIEW}

NUMBER: HNF-SD-FF-CN-006, ReV. 0

DOCUMENT REVIEWED: DECAY HEAT FRACTIONS FOR DFA 8213 AND 4192

AUTHOR(s): SF Kessler

I. Method(s) of Review

( In Inut data checked for accuracy

(NA) Independent calculation performed

( ) Hand calculation

() Alternate computer code:

(hiA) Comparison to experiment or previous results

( ${ }^{\prime} \rightarrow$ ) Alternate method (define)

II. Checklist (either check or enter NA if not applied)

( $\checkmark$ ) Task completely defined

(v) Activity consistent with task specification

(V) Necessary assumptions explicitly stated and supported

( $)$ Resources properly identified and referenced

(b) Resource documentation appropriate for this application

(r) Input data explicitly stated

(v) Input data verified to be consistent with original source

( $)$ Geometric model adequate representation of actual geometry

(.) Material properties appropriate and reasonable

( $\mathrm{NA}$ ) Mathematical derivations checked including dimensional consistency

( $N A)$ Hand calculations checked for errors

$(\checkmark)$ Assumptions explicitly stated and justified

(v) Computer software appropriate for task and used within range of validity

(NA) Use of resource outside range of established validity is justified

( $\sim$ ) Software runstreams correct and consistent with results

( $\sim$ ) Software output consistent with input

$(\checkmark)$ Results consistent with applicable previous experimental or analytical findings

$(\checkmark)$ Results and conclusions address all points and are consistent with task requirements and/or established limits or criteria

(r) Conclusions consistent with analytical results and established limits

(NA) Uncertainty assessment appropriate and reasonable

$\left(N_{A}\right)$ Other (define)

III. Comments :

IV. REviewer: $K \perp$ Eoblim DATE: $\quad 1-23-47$ 


\begin{tabular}{|c|c|c|c|c|c|}
\hline \multicolumn{6}{|c|}{ DISTRIBUTION SHEET } \\
\hline \multirow{2}{*}{$\begin{array}{l}\text { To } \\
\text { Distribution }\end{array}$} & \multirow{2}{*}{\multicolumn{3}{|c|}{$\begin{array}{l}\text { From } \\
\text { Criticality and Shielding }\end{array}$}} & \multicolumn{2}{|c|}{ Page 1 of 1} \\
\hline & & & & \multicolumn{2}{|c|}{$\begin{array}{l}\text { Date } \\
\text { January 24, } 1997\end{array}$} \\
\hline \multirow{2}{*}{\multicolumn{4}{|c|}{$\begin{array}{l}\text { Project Title/Work Order } \\
\text { Decay Heat Fractions for DFA } 8213 \text { and } 4192\end{array}$}} & \multicolumn{2}{|c|}{ EDT No. 620286} \\
\hline & & & & \multicolumn{2}{|c|}{ ECN No. } \\
\hline Name & MSIN & $\begin{array}{c}\text { Text } \\
\text { With All } \\
\text { Attach. }\end{array}$ & Text Only & $\begin{array}{l}\text { Attach./ } \\
\text { Appendix } \\
\text { Only }\end{array}$ & $\begin{array}{l}\text { EDT/ECN } \\
\text { Only }\end{array}$ \\
\hline K. D. Dobbin & $\mathrm{HO}-35$ & $x$ & & & \\
\hline J. Greenborg & HO-35 & $x$ & & & \\
\hline B. K. Howard & $\mathrm{N} 2-13$ & $x$ & & & \\
\hline S. F. Kessler & $\mathrm{HO}-35$ & $x$ & & & \\
\hline J. R. Vincent & $\mathrm{N} 2-02$ & $x$ & & & \\
\hline W. V. Witherspoon & N2-13 & $x$ & & & \\
\hline Central Files (Original +3 ) & $A 3-88$ & $x$ & & & \\
\hline
\end{tabular}

